\title{
BESZÁMOLÓ A SOFT CAPS 2019 GYAKORLATRÓL
}

\author{
Soucz Ferenc
}

Szerzô e-mail címe:

soucz.ferenc@mil.hu

Soucz Ferenc (2019): Beszámoló a SOFT CAPS 2019 gyakorlatról. Lélektan és hadviselés interdiszciplináris folyóirat, I. évf. 2019/1. szám. 87-89.

doi: $\underline{10.35404 / \text { LH.2019.1.87 }}$

A „SOFT CAPS 19” nemzetközi CIMIC harcászati és törzsvezetési gyakorlatra 2019.05.06 és 2019.06.30. között került sor az MH Ludovika Zászlóalj Ócsa Kiképzőbázisán az alábbi nemzetek, civilkatonai együttműködési (civil-military cooperation, CIMIC, illetve az USA terminológia szerint Civil Affairs, CA) szakembereinek részvételével: Bulgária, Egyesült Államok, Észak-Macedónia, Románia, Szlovénia, Szlovákia, Csehország, Németország, Lengyelország, Magyarország. A SOFT CAPS gyakorlat az $\mathrm{MH}$ CKELMK 2016 óta évente megrendezett saját gyakorlata. A megnevezés többszörösen is jelképes:

1. Az angol elnevezés a gyakorlat nemzetközi jellegére utal.

2. A „Soft Caps” szó szerinti fordításban: „puha sapka”, a feladat sajátosságának jelképe, vagyis az egyének és a szervezetek között létrejövő interakció szimbóluma.

3. A „caps” az angol „capabilities” szó (magyarul: képességek) rövidítésének is tekinthető, jelezve ezzel, hogy az MH CKELMK nem kinetikus képességekkel járul hozzá a műveletek sikeréhez.

A Központ szakemberei a kapcsolattartás, a kölcsönös informálódás és a támogató viszony kiépítése által a - klasszikusan vett katonai képességekkel nehezen lefedett - civil és információs környezetről alakítanak ki átfogó képet, amellyel hozzájárulnak a parancsnok munkájának támogatásához, döntéseinek előkészítéséhez és a kölcsönösen támogató civil környezet létrehozásához.

Katonáink a világ számos pontján találkoznak helyi vezetőkkel, szervezetek kép- 
viselőivel és a lakosság különféle rétegeivel. E feladatok gyakoroltatása szükségessé tette egy kifejezetten a nem kinetikus képességekre koncentráló gyakorlat létrehozását.

A SOFT CAPS gyakorlatra 2016-ban az MH Altiszti Akadémia csobánkai gyakorlóterén, majd 2017-től az MH Ludovika Zászlóalj Ócsa Kiképzőbázisán kerül sor.

Már az első alkalommal egyértelmú volt, hogy az alakulat egyedi feladatrendszerét gyakoroltatni csupán honvédségi erőforrásokkal nem lehet. A feladatok végrehajtásában nagy szerepet kapnak a gyakorlóterek közvetlen közelében található közigazgatási, katasztrófa- és rendvédelmi szervek, valamint számos nem kormányzati szervezet képviselői. Ök biztosítják, hogy a gyakorlat megfelelő módon szimulálja azt az összetett rendszert, amellyel katonáink műveleti területen kerülnek kapcsolatba. Ez a valós környezet nagymértékben segíti a felkészülést mind a hazai, mind a nemzetközi feladatokra.

A SOFT CAPS gyakorlatok végrehajtása és elemzése kapcsán a katonai és közigazgatási oldalról éppúgy, mint a lakosságtól pozitív visszajelzés érkezett. A megkeresett polgármesterek, rendőr- és tûzoltóparancsnokok, továbbá a civil szervezetek képviselői, sőt még a lakosság is segítőkészen fogadta kezdeményezésünket, valamint jelezték további támogatásukat a jövőben megszervezendő gyakorlatokhoz.

Ezek minden évben az aktuális szakmai feladatok gyakorlását, saját állományunk szakmai tudásának szinten tartását, vala- mint a közeljövőben várható új feladatok, új eljárások tesztelését tűzte ki célul. Mindezt azért, hogy a Magyar Honvédség alakulat-parancsnokai számára egyre szélesebb körű alternatív megoldási javaslatokkal szolgálhassunk.

„A SOFT CAPS 19” gyakorlat keretében Magyarországra települt a Többnemzeti Civil-katonai Együttmúködési Központ (Multinational CIMIC Centre, MNCC), mely központ az

- IMMEDIATE RESPONSE, - SZENTES AXE,

- SABER GUARDIAN, - BREAKTHROUGH, - DECISIVE STRIKE

gyakorlatok CIMIC valós biztosítását koordinálta.

Az MNCC része az Európában Állomásozó Amerikai Szárazföldi Haderő Parancsnokság (USAREUR) szervezésében 2019. május 10 - június 24. között egy ún. „nagyláthatóságú” gyakorlatnak, amelyik Magyarországon, Romániában, Bulgáriában, Szlovéniában, Horvátországban és Észak-Macedóniában zajlott. Célja a Közép-Kelet Európai és a Fekete-tengeri Régió stabilitásának és biztonságának erôsítése, az amerikai jelenlét demonstrálása, illetve az USA és a szövetséges erők együttmúködési képességének fejlesztése.

2019. június 17-22 közötti időszakban az MNCC bevonásával zajlott az $\mathrm{MH}$ CKELMK éves harcászati gyakorlata a V4 nemzetek és Németország részvételével, 
szintén Ócsán. Az összlétszám ekkor közel 80 fő volt.

\section{Kitürött célok:}

- Hazai környezetben begyakoroltatni a CIMIC szakállományt, hogy a múveleti területen hogyan múködjön együtt a helyi szervezetekkel, állami és nem állami szereplőkkel.

- A végrehajtói CIMIC technikák gyakoroltatása.

-Zászlóaljszintű, többnemzeti CIMIC szakmai vezetési elem Többnemzeti Civil-katonai Együttmúködési Központ (MNCC) törzsi funkcióinak begyakorlása.

- A V4-es CIMIC szakmai kapcsolatok erősítése, az interoperabilitás fokozása.

- Többnemzeti Civil-katonai Együttmúködési Központ (MNCC) létrehozása, eljárási rendjének kialakítása.

- Átfogó képet kialakítani a civil és információs környezetről, amellyel hozzájárulnak a parancsnok munkájának támogatásához, döntéseinek előkészítéséhez.
Mindennek keretében megfogalmazott általános célok:

\section{Civil-katonai kapcsolattartás}

A mûveletek sikeres végrehajtása a humanitárius katasztrófák elkerülése céljából, az emberi szenvedések enyhítése érdekében, valamint az együttmúködés megteremtése a különböző nemzetközi, regionális szervezetekkel és nem kormányzati szervekkel.

\section{A civil környezet támogatása}

Azoknak a polgári szükségleteknek a felmérése, melyek katonai forrásokból megvalósíthatók, és amelyek kielégítése a humanitárius katasztrófa bekövetkeztének - lehetőség szerinti - megelőzéséhez vezet, valamint a biztonság csökkenésének megakadályozásához alapvető fontosságú. A feladat sikeres ellátásához szükséges területfelmérés, értékelés elkészítése.

\section{A baderö támogatása}

A polgári erőforrások, lehetőségek felmérése, amelyek a haderő számára szükség esetén igénybe vehetők. 